\title{
Pengaruh Terapi Aktivitas Kelompok (TAK) : Stimulus Persepsi Sesi 1-3 Terhadap Kemampuan Mengontrol Halusinasi Pendengaran Pada Pasien Skizofernia
}

\author{
Pratiwi Gasril $^{1}$, Yeni Yarnita ${ }^{2}$, Putri Afrilliya ${ }^{3}$, Yeni Devita $^{4 *}$ \\ 1,2, 3 Universitas Muhammadiyah Riau \\ ${ }^{4 *}$ STIKes Payung Negri
}

Correspondence e-mail: pratiwi@umri.ac.id

\begin{abstract}
Schizophrenia is a mental disorder characterized by abnormalities in the perception or expression of reality. One of the most common symptoms in schizophrenia is the appearance of hallucinations, which is about 70\%. Purpose: This study is to effect Group Activity Therapy (TAK): Perception Stimulus sessions 1-3 on the Ability to Control Hearing Hallucinations in Schizophrenic Patients in Sebayang Room at Tampan Mental Hospital, Riau Province. This research research method is quantitative with a Quasi Experiment approach, conducted on 16 respondents from 03 to 13 March 2020 at the Tampan Mental Hospital, Riau Province. Researchers used the Auditory Hallucinations Rating Scale (AHRS) module and evaluation sheet before and after the intervention. The technique used univariate and bivariate analysis with Paired Sample T Test. The results showed a significant influence between Group Activity Therapy (TAK) Perceptual Stimulation of the Ability to Control Auditory Hallucinations, with a value of $p=0.01$.
\end{abstract}

Keywords : TAK Perception Stimulation, Controlling Ability

\begin{abstract}
Abstrak
Skizofrenia merupakan gangguan mental yang ditandai oleh kelainan dalam persepsi atau ungkapan realitas. Salah satu gejala yang paling sering muncul pada Skizofrenia adalah munculnya halusinasi yaitu sekitar 70 \%. Tujuan penelitian ini adalah untuk pengaruh Terapi Aktivitas Kelompok (TAK) : Stimulus Persepsi sesi 1-3 terhadap Kemampuan Mengontrol Halusinasi Pendengaran Pada Pasien Skizofrenia Di Ruangan Sebayang Rumah Sakit Jiwa Tampan Provinsi Riau. Metode penelitian penelitian ini adalah kuantitatif dengan pendekatan Quasi Eksperimen, dilakukan terhadap 16 responden pada tanggal $03 \mathrm{~s} / \mathrm{d}$ 13 Maret 2020 di Rumah Sakit Jiwa Tampan Provinsi Riau. Peneliti menggunakan modul dan lembar evaluasi Auditory Hallucinations Rating Scale (AHRS) sebelum dan sesudah intervensi. Teknik menggunakan analisis univariat dan bivariate dengan Uji Paired Sampel T Test. Hasil penelitian menunjukkan adanya pengaruh yang signifikan antara Terapi Aktivitas Kelompok (TAK) Stimulasi Persepsi Terhadap Kemampuan Mengontrol Halusinasi Pendengaran, dengan nilai $p=0,01$.
\end{abstract}

Kata Kunci : TAK Stimulasi Persepsi, Kemampuan Mengontrol

Received: November 2021, Accepted : November 2021 - Jurnal Photon Vol.12 No.1

DOI : https://doi.org/10.37859/jp.v12i1.3271

PHOTON is licensed under a Creative Commons Attribution-ShareAlike 4.0 International License 


\section{Introduction}

Skizofrenia merupakan gangguan mental yang ditandai oleh kelainan dalam persepsi atau ungkapan realitas. Salah satu gejala yang paling sering muncul pada Skizofrenia adalah munculnya halusinasi yaitu sekitar $70 \%$. Gangguan persepsi sensori (halusinasi) merupakan salah satu masalah keperawatan yang dapat ditemukan pada pasien gangguan jiwa. Pasien merasakan sensasi berupa suara, penglihatan, pengecapan, perabaan atau penghidu, tanpa stimulus yang nyata. Salah satu jenis halusinasi yang paling sering dijumpai yaitu halusinasi pendengaran. Halusinasi pendengaran dapat berupa bunyi mendenging atau suara bising yang tidak mempunyai arti, tetapi lebih sering terdengar sebagai sebuah kata atau kalimat yang bermakna (Haryana 2015).

Asuhan keperawatan jiwa merupakan asuhan keperawatan spesialistik, namun tetap dilakukan secara holistik pada saat melakukan asuhan kepada pasien. Berbagai terapi keperawatan yang dikembangkan, salah satu terapi keperawatan jiwa yang terbukti efektif untuk mengatasi gejala gangguan jiwa adalah terapi aktivitas kelompok (TAK), difokuskan kepada pasien, secara individu, kelompok, keluarga maupun komunitas. Terapi Aktivitas Kel,ompok terdiri dari empat yaitu terapi aktivitas kelompok stimulasi kognitif/persepsi, terapi aktivitas kelompok stimulasi sensori, terapi aktivitas kelompok orientasi realita, dan terapi aktivitas kelompok sosialisasi. Aktivitas digunakan sebagai terapi, dan kelompok digunakan sebagai target asuhan, di dalam kelompok terjadi dinamika interaksiyang saling bergantung, saling membutuhkan dan menjadi laboratorium tempat pasien berlatih perilaku baru yang adaptif untuk memperbaiki perilaku lama yang maladaptive (Anna Keliat 2011).

Terapi Aktivitas Kelompok: Stimulasi Persepsi bertujuan agar pasien dapat mempersepsikan stimulus yang dipaparkan kepadanya dengan tepat dan dapat menyelesaikan masalah yang timbul dari stimulus yang dialami dan dapat membantu pasien mengenali dan mengontrol gangguan halusinasi yang dialaminya (Haryana 2015). Hasil penelitian terdahulu yang dilakukan oleh Ari \& Rochdiat dengan judul pengaruh pemberian terapi aktivitas kelompok stimulasi persepsi terhadap kemampuan mengontrol halusinasi pada klien skizofrenia di Rumah Sakit Ghrasia menunjukkan bahwa nilai rata-rata kemampuan mengontrol sebelum dilakukan terapi aktivitas kelompok stimulasi persepsi adalah 1,97 dan nilai rata-rata kemampuan mengontrol halusinasi setelah dilakukan terapi aktivitas kelompok stimulasi persepsi adalah 2,62. Hal tesebut berarti ada pengaruh terapi aktivitas kelompok stimulasi persepsi terhadap kemampuan mengontrol halusinasi pada klien skizofrenia di Rumah Sakit Ghrasia (Suryanti. et al. 2017).

Hasil wawancara yang di lakukan peneliti pada tanggal 11 Desember 2019 terdapat 25 pasien dengan Halusinasi Pendengaran, dan untuk survey awal ini peneliti mengambil 7 pasien sebagai sampel, dan di dapatkan bahwa 4 orang pasien mengatakan bahwa sering mendengar suara-suara aneh yang mengganggunya pada saat sedang sendiri dan mereka belum bisa mengontrol bagaimana

Received: November 2021, Accepted : November 2021 - Jurnal Photon Vol.12 No.1

DOI : https://doi.org/10.37859/jp.v12i1.3271

PHOTON is licensed under a Creative Commons Attribution-ShareAlike 4.0 International License 
cara menghilangkan suara aneh tersebut, 2 orang lainnya mengatakan sudah tidak terlalu sering mendengar suara aneh dan mereka pun belum bisa mengontrol bagaimana cara menghilangkan suara aneh, 1 orang lagi belum terlalu paham mengenai suara-suara yang sering di dengarnya dan belum mengerti bagaimana cara menghilangkan suara tersebut, dan 1 orang dari 7 responden tidak sering mendengar suara aneh tetapi sudah bisa mengontrol bagaimana menghilangakan suara tersebut dengan cara menghardik. Dan dari hasil wawancara bersama perawat di RSJ bahwasannya dalam pelaksanaan terapi aktivitas kelompok, pasien dengan halusinasi pendengaran belum terlalu memahami tentang apa yang dirasakan dan didengarkannya.

\section{The Methods}

Jenis penelitian yang digunakan dalam penelitian ini adalah penelitian quasi eksperimen) jenis One group pretest-posttest yang hanya terdiri dari 1 kelompok. Pada rancangan ini tidak ada kelompok pembanding (kontrol), tetapi dilakukan observasi awal (pretest) terlebih dahulu sebelum diberikan intervensi, setelah itu diberikan intervensi kemudian dilakukan observasi akhir (posttest) (Alimul,2007 dalam dari Sihotang, 2010).

Populasi adalah keseluruhan obyek penelitian atau obyek yang akan dilakukan penelitian (Notoatmodjo, 2010). Berdasarkan defenisi di atas, populasi dalam penelitian ini adalah pasien skizofrenia dengan Halusinasi Pendengaran di ruang rawat inap Sebayang dengan jumlah 16 orang,di Rumah Sakit Jiwa Tampan Pekanbaru.

Sampel adalah sebagian yang diambil dari keseluruhan obyek untuk diteliti dan dianggap mewakili seluruh populasi (Notoatmodjo, 2010).Teknik pengambilan sampel dalam penelitian ini adalah Purposive sampling. Purposive sampling adalah salah satu teknik sampling non random sampling dimana peneliti menentukan pengambilan sampel dengan cara menetapkan ciri-ciri khusus yang sesuai dengan tujuan penelitian. Yang menjadi kriteria atau ciri-ciri khusus pada sampel adalah sebagai berikut :Kriteria Inklusi yaitu : Pasien dengan halusinasi pendengaran, Pasien yang dirawat di ruang Sebayang Rumah Sakit Jiwa Tampan Pekanbaru,Pasien yang Kooperatif, Pasien yang bersedia menjadi responden. Kriteria Eksklusi yaitu : Tidak bersedia menjadi responden, Sedang berhalusinasi, Sedang di isolasi (Pengikatan).

Pengumpulan data yang digunakan dalam penelitian ini adalah berupa lembar observasi. Bagian pertama instrument penelitian tentang pengumpulan data demografi pasien yang meliputi: umur, tingkat pendidikan, jenis halusinasi, dan lama hari rawat. Bagian kedua terdiri dari : lembar observasi. Lembar observasi berisi beberapa item observasi yang menggambarkan kemampuan pasien mengontrol halusinasi. Konsepnya diadopsi dari Terapi Aktivitas Kelompok Stimulasi Persepsi oleh Budi Anna Keliat. Penilaian menggunakan Skala Gultman dengan pilihan jawaban ( ya / tidak), dengan nilai sebagai berikut : "Ya" diberi skor 2 dan jika "Tidak" diberi skor 1.

Received: November 2021, Accepted : November 2021 - Jurnal Photon Vol.12 No.1

DOI : https://doi.org/10.37859/jp.v12i1.3271

PHOTON is licensed under a Creative Commons Attribution-ShareAlike 4.0 International License 


\section{Result and Discussion}

Tabel 1. Distribusi Frekuensi Responden Berdasarkan Kemampuan Mengontrol Halusinasi Sebelum dan Setelah TAK: Stimulasi Persepsi Sesi 1-3 Di Ruang Sebayang RSJ Tampan Provinsi Riau Tahun $2020(\mathrm{n}=16)$

\begin{tabular}{lllll}
\hline Variabel & Mean & SD & SE & P Value \\
\hline PreTest & 14.37 & 1.669 & 814 & 0,01 \\
PostTest & 20.68 & 2.337 & 584 & \\
\cline { 1 - 3 } Selisih & 6.31 & 668 & 230 & \\
\hline
\end{tabular}

Hasil penelitian yang dilakukan peneliti di Ruang Sebayang Rumah Sakit Jiwa Tampan Provinsi Riau pada tanggal 03 - 13 Maret 2020 memperoleh hasil mayoritas kemampuan mengontrol halusinasi pendengaran responden setelah diberikan Terapi Aktivitas Kelompok dalam kategori mampu mengontrol yang berjumlah 16 responden (100.0\%), sedangkan responden yang memiliki kategori tidak mampu mengontrol berjumlah 0 responden $(0.0 \%)$. Hal ini dapat dilihat bahwa rata-rata nilai mean sebelum dilakukan Terapi Aktivitas Kelompok adalah 14.37\%, dan sesudah dilakukan Terapi Aktivitas Kelompok adalah 20.68\% dengan selisih 6.31\% dan dibuktikan dengan P-Value =0,01< 0,05, yang artinya ada pengaruh Terapi Aktivitas Kelompok : Stimulasi Persepsi Sesi 1-3 Terhadap Kemampuan Mengontrol Halusinasi Pendengarann Pada Pasien Skizofrenia.

Hasil penelitian ini sesuai dengan hasil penelitian yang dilakukan oleh (Aristina Halawa, 2015) pengaruh TAK: Stimulasi Persepsi terhadap kemampuan mengontrol halusinasi pendengaran pada pasien skizofrenia didapatkan hasil p=0.025 arti ada pengaruh Terapi Aktivitas Kelompok: Stimulasi Persepsi Sesi 1-2 terhadap kemampuan mengontrol halusinasi pendengaran pada pasien skizofrenia di Ruang Flamboyan Rumah Sakit Jiwa Menur Surabaya. Hal ini kemungkinan dikarenakan adanya ketertarikan responden terhadap pelaksanaan TAK yang membuat pengetahuan pasien semakin bertambah sehingga membuat kemampuan mengontrol halusinasi dapat mengalami peningkatan.

Hasil penelitian ini sesuai dengan hasil penelitian yang dilakukan oleh (Ellina 2012) Pengaruh TAK Stimulasi Persepsi Terhadap Kemampuan Memutus Halusinasi Pada Klien Skizofrenia Dari hasil statistik wilcoxon signed ranks test didapat $\mathrm{p}=0,014$ yang artinya ada perbedaan yang nyata antara kemampuan memutus halusinasi sebelum dan sesudah diberikan TAK stimulasi persepsi pada klien skizofrenia.

Hasil penelitian ini sesuai dengan hasil penelitian yang dilakukan (Muhammad Qodir et al. 2013) Pengaruh terapi aktivitas kelompok stimulus persepsi terhadap kemampuan mengontrol halusinasi pendengaran di rumah sakit khusus daerahb provinsi sumatra selatan di adapatkan hasil

Received: November 2021, Accepted : November 2021 - Jurnal Photon Vol.12 No.1

DOI : https://doi.org/10.37859/jp.v12i1.3271

PHOTON is licensed under a Creative Commons Attribution-ShareAlike 4.0 International License 
pvalue $=0.005$ kurang dari a $=0.05$ yang artinya ada pengaruh terapi aktivitak kelompok stimulus persepsi terhadap kemampuan mengontrol halusinasi pendengaran setelah diberikan terapi.

Hasil penelitian ini sesuan dengan penelitian (Emiliani, 2010) Hasil penelitian menunjukkan bahwa kemampuan mengendalikan halusinasi sesudah diberikan TAK Stimulasi Persepsi Halusinasi pendekatan Health Belief Model, sebanyak 5 orang (55,6\%) mampu mengendalikan halusinasi dengan nilai $\mathrm{p}(0,0001)<0,05$ berarti ada perbedaan signifikan kemampuan mengendalikan halusinasi sebelum dan sesudah pemberian TAK Stimulasi Persepsi Halusinasi pendekatan Health Belief Model.

Menurut asumsi peneliti bahwa kemampuan mengontrol halusinasi sebelum diberikan terapi aktivitas kelompok stimulasi persepsi dilakukan 2 kali setiap masing- masing sesinya, didapatkan hasil bahwa hari ke 2 adalah yang mampu mengontrol halusinasi sebelum diberikan TAK dengan jumlah 5 responden, dan kemampuan mengontrol halusinasi setelah diberikan terapi aktivitas kelompok stimulasi persepsi juga dilakukan 2 kali setiap masing- masing sesinya, serta didapatkan hasil bahwa hari ke 2 adalah yang mampu mengontrol halusinasi setelah diberikan TAK dengan jumlah 16 responden.

\section{Conclusion}

Penelitian ini dilakukan pada 16 responden dengan tujuan untuk membuktikan Kemampuan pasien skizofrenia dalam mengontrol halusinasi pendengaran sebelum pemberian Terapi Aktivitas Kelompok: Stimulasi Persepsi Sesi 1-3 didapatkan bahwa pasien yang mampu mengontrol halusinasi sebanyak 5 responden

Kemampuan pasien skizofrenia dalam mengontrol halusinasi pendengaran setelah pemberian Terapi Aktivitas Kelompok: Stimulasi Persepsi Sesi 1-3 didapatkan sebagian besar responden mampu mengontrol halusinasi sebanyak 16 responden.

Dari hasil uji statistik di peroleh $\mathrm{p}$-value $=0,01$ maka dapat di simpulkan Ada pengaruh Terapi Aktivitas Kelompok: Stimulasi Persepsi Sesi 1-3 terhadap kemampuan mengontrol halusinasi pendengaran pada pasien skizofrenia.

\section{Acknowledgement}

Terima kasih diucapkan kepada seluruh responden yang bersedia berpartisipasi dalam penelitian ini

Received: November 2021, Accepted : November 2021 - Jurnal Photon Vol.12 No.1

DOI : https://doi.org/10.37859/jp.v12i1.3271

PHOTON is licensed under a Creative Commons Attribution-ShareAlike 4.0 International License 


\section{References}

Anna Keliat. 2011. “Terapi Aktivitas Kelompok(TAK),” 126.

Aristina Halawa. 2015. "Pengaruh TAK Stimulasi Persepsi Sesi 1-2 Terhadap Kemampuan Mengontrol Halusinasi.

Ellina, Agusta Dian. 2012. "Pengaruh Terapi Aktifitas Kelompok (Tak) Stimulasi Persepsi Sessi 1-3 Terhadap Kemampuan Mengendalikan Halusinasi Pada Pasien Skizofrenia Hebefrenik. Jakarta." STRADA Jurnal Ilmiah Kesehatan 1 (1): 56-62.

Emilyani, Desty. 2015. "Peningkatan Kemampuan Mengendalikan Halusinasi Pada Pasien Skizofrenia Dengan Tak" 3 (2): 159-68.

Haryana, K M Syarif. 2015. “TAK Stimulus Persepsi, Di Ruang Flamboyan, Rumah Sakit Jiwamenur, Surabaya" 2 (1): 14-21.

Muhammad Qodir, Aksi, Ns Anjas Surtiningrum, Ulfa Nurullita, Ilmu Keperawatan STIKES Telogorejo Semarang, Dosen STIKES Telogorejo Semarang, and Dosen Universitas Muhammadiyah Semarang. 2013.

Sihotang, Ledy Gresia. 2010. “RUMAH SAKIT JIWA DAERAH PROVSU MEDAN.

Suryanti., Vevi, Rumah Sakit, rawat inap Provinsi, Terapi Arjuna, Kelompok Stimulasi, Persepsi Halusinasi, and Kemampuan Mengontrol . jambi : stikes baiturahman Halusinasi. 2017. "Pengaru Tak Stimulasi Persepsi Halusinas Terhadap Kemampuan Mengontrol Halusinasi. Jambi" 6 (2): 174-83.

Received: November 2021, Accepted : November 2021 - Jurnal Photon Vol.12 No.1 DOI : https://doi.org/10.37859/jp.v12i1.3271 